\title{
PETA PENGEMBANGAN EKONOMI BERBASIS MASYARAKAT UNTUK MENINGKATKAN KETANGGUHAN MASYARAKAT DAERAH RAWAN BENCANA.
}

\author{
Eka Kadharpa Utama Dewayani ${ }^{1}$ \\ Ruli Inayah Ramadhoan ${ }^{2}$ \\ Program Studi Akuntansi,Universitas Muhammadiyah Malang ${ }^{1}$
}

\begin{abstract}
Abstrac
Malang City is one area that has the potential for disasters to spread throughout the subdistrict even though with different types of disasters. The observation result of Class II Climatology Station Malang stated that Malang City had relatively high rainfall up to $300 \mathrm{~mm}$. Bareng Village is one of the flood-prone areas each year. This disaster has an impact on the decline in the economy of society that is difficult to recover. So far, the City Government of Malang does not yet have an effective solution formulation based on the characteristics of the community's basic needs. This study aims to find a model of community economic development in disaster-prone areas based on structured business management and can be a comprehensive evaluation and recommendation material for local governments in determining economic programs for people in disaster-prone areas. This research uses the theory of competitive advantage strategy and product differentiation strategy concepts. The method used is Participatory Planning with the Rapid Rural Appraisal (RRA) approach, which is a method of understanding locations by learning from, for and with the community, to find out, analyze and evaluate obstacles and opportunities so that an increase in the community's economy can be maximized and adjusted to the actual conditions of the community. The results of this study found that to develop the economy of communities in disaster prone areas requires a model of mapping economic potential by actively involving people in disaster prone areas by inviting them to jointly determine, conceptualize, and oversee the strategies and types of businesses they will develop until the process of conducting business independently.
\end{abstract}

Keywords: Economic Improvement, Business Management, Disaster Resilient Communities

\begin{abstract}
Abstrak
Kota Malang merupakan salah satu daerah yang memiliki potensi bencana menyebar di seluruh wilayah kecamatan meskipun dengan tipe bencana yang berbeda-beda. Hasil pengamatan Stasiun Klimatologi Kelas II Malang menyebutkan bahwa Kota Malang memiliki curah hujan yang relatif tinggi hingga $300 \mathrm{~mm}$. Kelurahan Bareng merupakan salah satu wilayah rawan banjir tiap tahunnya. Bencana ini berdampak pada menurunnya perekonomian masyarakat yang sulit pulih kembali. Selama ini Pemerintah Kota Malang belum memiliki formulasi solusi yang efektif berdasarkan karakteristik kebutuhan dasar masyarakat Bareng. Penelitian ini bertujuan menemukan model pengembangan ekonomi masyarakat di wilayah rawan bencana dengan berbasis manajemen bisnis yang terstruktur dan dapat menjadi bahan evaluasi dan rekomendasi yang komperehensif bagi pemerintah daerah dalam menentukan program-program bidang ekonomi bagi masyarakat wilayah rawan bencana. Penelitian ini menggunakan teori strategi keunggulan bersaing dan konsep strategi diferensiasi produk. Adapun metode yang digunakan yaitu Perencanaan Partisipatif dengan pendekatan Rapid Rural Appraisal (RRA) yaitu metode pemahaman lokasi dengan cara belajar dari, untuk dan bersama masyarakat, untuk mengetahui, menganalisis dan mengevaluasi hambatan dan kesempatan sehingga peningkatan perekonomian masyarakat bisa dimaksimalkan dan disesuaikan dengan kondisi masyarakat sebenarnya. Hasil penelitian ini menemukan bahwa untuk mengembangkan ekonomi masyarakat di wilayah rawan bencana membutuhkan model pemetaan potensi ekonomi dengan cara mengikutsertakan masyarakat wilayah rawan bencana secara aktif dengan cara mengajak mereka secara bersama-sama menentukan, mengonsep, dan mengawal strategi dan jenis usaha yang akan mereka kembangkan hingga proses pelaksanaan bisnis secara mandiri.
\end{abstract}

Kata Kunci: Peningkatan Ekonomi, Manajemen Bisnis, Masyarakat Tangguh bencana

\section{Pendahuluan}

Bencana adalah suatu peristiwa atau rangkaian kejadian yang mengakibatkan korban penderitaan manusia, kerugian harta benda, kerusakan lingkungan, sarana dan prasarana serta dapat menimbulkan gangguan terhadap tata kehidupan dan penghidupan masyarakat (Awange, 2012; Victoria, Director, Preparedness, \& Center for Disaster Preparedness, 2002). Kejadian bencana juga dipicu seiring meningkatnya aktivitas manusia(Lindell, 2013; Tingsanchali, 2012). Kota Malang merupakan salah satu

\footnotetext{
1 dewayani62@yahoo.co.id
}

2 ruliramadhoan@gmail.com 
daerah yang memiliki potensi bencana menyebar di seluruh wilayah kecamatan meskipun dengan tipe bencana yang berbeda-beda. Hasil pengamatan Stasiun Klimatologi Kelas II Karangploso Malang per 24 Agustus 2016 menyebutkan bahwa Kota Malang memiliki curah hujan yang relatif tinggi hingga $300 \mathrm{~mm}$. Kelurahan Bareng yang memiliki kondisi hidrometeorologis beragam merupakan salah satu wilayah rawan banjir. Kawasan RW VII dan RW VIII selama ini menjadi langganan banjir selama musim hujan. Bencana ini sangat berdampak pada masyarakat karena termasuk dalam kawasan padat penduduk.

Hasil asessemen awal rehabilitasi dan rekonstruksi (A2R2) menunjukkan berbagai akibat, dampak dan kebutuhan pasca bencana. Pada segi infrastruktur, belum adanya dinding penahan menyebabkan air menggenang. Hal ini dikarenakan adanya aliran air dari berbagai sumber mata air diantaranya dari saluran drainase Perumahan Ijen Nirwana, saluran drainase Pulosari dan saluran air pemukiman Bareng. Hal tersebut diperparah dengan adanya sedimentasi/ endapan di saluran air ditambah dengan perilaku masyarakat yang membuang limbah cair rumah tangga ke saluran. Genangan air menyebabkan berbagai kerugian, seperti masuknya air ke rumah warga, rusaknya perabotan rumah, tangga sebagai akses jalan menjadi licin sehingga membahayakan warga. Akses jalan menjadi terganggu dan tidak berfungsi. Kondisi ini juga dapat meningkatkan risiko pada kesehatan warga dan dapat menimbulkan longsor.

Selain itu pada aspek ekonomi, kegiatan perekonomian masyarakat menjadi terganggu akibat air yang masuk di tempat usaha mereka. Keadaan ini berdampak pada pendapatan masyarakat yang berarti terjadi penurunan kapasitas perekonomian yang berimplikasi terhadap produksi domestik regional bruto. Secara psikologis, korban bencana mengalami kondisi traumatis yang dapat menghilangkan motivasi kerja serta dorongan untuk maju dan berkembang. Dalam hal ini diketahui bahwa dampak bencana bukan hanya pada aspek fisik seperti bangunan, perumahan dan permukiman tetapi juga pada aspek sosial ekonomi, budaya dan psikologis.

Salah satu kegiatan penting dalam manajemen bencana terutama pada tahap pasca bencana adalah aktivitas rehabilitasi dan rekonstruksi (Rathore et al., 2012; Reinhardt et al., 2011). Tahap ini diawali dengan pengkajian kebutuhan pasca bencana (jitupasna). Dilanjutkan dengan pengkajian kebutuhan pemulihan dengan komponen pembangunan, penggantian, penyediaan bantuan akses, pemulihan fungsi, dan pengurangan risiko. Hal ini dimaksudkan untuk mengetahui kebutuhan prioritas rehabilitasi dan rekonstruksi dalam rangka memulihkan kembali seperti pada kondisi sebelum bencana. Jika dimungkinkan pada tahap ini untuk menciptakan kondisi fisik, sosial, ekonomi serta psikologis masyarakat agar menjadi lebih baik dibandingkan sebelum terjadinya bencana.

Pada konteks Kelurahan Bareng yang terdampak bencana banjir dipandang perlu memulihkan kembali dan meningkatkan keadaan sosial ekonomi, budaya dan psikologis masyarakat sebagai aspek prioritas rehabilitasi dan rekonstruksi pasca bencana. Membangun menjadi lebih baik dan lebih aman (build back better and safer) yang terpadu dengan mengedepankan konsep pengurangan risiko bencana (disaster risk reduction). Pemulihan dilakukan melalui optimalisasi pemanfaatan sumber daya setempat sebagai pendukung pemulihan aktivitas sosial dan kemandirian masyarakat. Langkah ini tentunya dengan memperhatikan kondisi dan karakteristik sosial budaya masyarakat setempat. Diawali dari serangkaian kajian rehabilitasi rekonstruksi yang mendasari tahap selanjutnya yaitu penyusunan Rencana Aksi (RenAksi) Rehabilitasi Rekonstruksi Badan Penanggulangan Bencana Daerah Kota Malang. Dalam hal ini BPBD Kota Malang fokus pada kegiatan pemulihan sosial ekonomi, budaya dan psikologis masyarakat terdampak bencana.

Hal ini menjadi penting karena kondisi sosial ekonomi, budaya dan psikologis yang baik akan mampu meningkatkan taraf hidup masyarakat. Oleh karena itu, pekerjaan Pengkajian Kebutuhan Sosial, Ekonomi, Budaya dan Psikologis Pasca Bencana di RW VII dan RW VIII Kelurahan Bareng melalui Metode Rapid Rural Appraisal (RRA) dan Focus Group Discussion (FGD) dilakukan untuk mendasari penyusunan RenAksi RR di Kelurahan Bareng, Kecamatan Klojen, Kota Malang Tahun 2016. Dimana pengkajian ini bertujuan untuk mendapatkan gambaran tentang berbagai potensi pengembangan ekonomi yang dimiliki di Kawasan Kelurahan Bareng dan karakteristik perilaku bisnis warganya, serta bertujuan untuk mengukur posibilitas usaha pengembangan ekonomi masyarakat terdampak bencana dan menentukan bidang, jenis, strategi, sistem pengelolaan bisnis yang berfokus pada peningkatan perekonomian sesuai dengan kondisi masyarakat terdampak bencana.

\section{Metode Penelitian}

Survei dilakukan di beberapa RW.07 dan RW.08 Kelurahan Bareng Kota Malang. Adapun penunjukan responden yang digunakan dalam survei ini dengan sample total yang berdasarkan data acuan dari Kelurahan Bareng. Responden sedapat mungkin dipusatkan pada masyarakat terdampak bencana banjir untuk mendapatkan objektifitas dan realiabilitas data. Adapun kriteria responden terpilih adalah berumur 17 tahun atau lebih, atau sudah menikah pada saat survei dilakukan. 
Responden terpilih diwawancarai oleh surveyor yang terlatih. Sebagai kontrol, tiap responden akan diberikan kartu kontrol yang nantinya akan didatangi lagi oleh Spot Checker sebagai pengecekan ulang apakah wawancara benar-benar dilakukan dan apakah surveyor menanyakan semua daftar pertanyaan yang ada dalam kuisioner. Quality control dilakukan terhadap 20 persen responden secara acak dan dilakukan oleh Spot Checker.

Survei ini menggunakan Metode Perencanaan Partisipatif dengan pendekatan Rapid Rural Appraisal (RRA) yaitu suatu metode pemahaman lokasi dengan cara belajar dari, untuk dan bersama masyarakat, untuk mengetahui, menganalisis dan mengevaluasi hambatan dan kesempatan melalui multidisiplin. Dalam RRA, informasi dikumpulkan oleh pihak luar (outsiders), kemudian data dianalisa untuk menyusun perencanaan pembangunan yang sesuai potensi masyarakatnya. Pendekatan RRA bersifat penggalian informasi bersama-sama masyarakat mulai dari pengumpulan informasi, analisa sampai pada perencanaan program.

\section{Hasil Dan Pembahasan}

\section{Pengembangan Jaringan Air Bersih dan Sanitasi Lingkungan}

Sarana dan Prasaran dalam kasus daerah terdampak bencana banjir di Kota Malang terdapat dua komponen penting dalam hal perbaikan sarana prasarana umum terkait jaringan infrastruktur fisik yang memerlukan perhatian khusus (priority) yaitu jaringan air bersih dan jaringan sanitasi dan limbah. Jaringan air bersih meliputi sumber-sumber air, jaringan distribusi, dan hidan-hidran umum dengan indikator tersedianya kembali suplai air bersih, penyelamatan sumber air dari pencemaran atau kerusakan. Sedangkan jaringan sanitasi dan limbah meliputi jaringan air kotor, limbah sampah padat, dan fasilitas pemakaman dengan indikator terciptanya lingkungan yang bersih dan bebas dari gangguan limbah.

Jaringan dan Sumber Air Bersih, adapun berkenaan dengan jaringan air bersih di Kelurahan Bareng Kecamatan Klojen, khususnya RW 07 dan 08 yang merupakan wilayah terdampak bencana banjir di Kota Malang terkait dengan elemen sumber air yang digunakan oleh masyarakat sesuai dengan pemanfaatannya dibedakan menjadi dua yaitu untuk memasak dan kepeluan mandi, cuci, kakus (MCK). Hasil survei menggambarkan bahwa sumber air yang digunakan untuk memasak oleh masyarakat sebagian besar bersumber pada aliran yang dikelola oleh Perusahaan Daerah Air Minum (PDAM) yaitu mencapai $58 \%$, sedangkan yang bersumber dari sumur mencapai 33\% dan yang terkecil jumlahnya dengan menggunakan air kemasan mencapai 8,8\%. Dari penjelasan diatas dapat dijelaskan bahwa sebagian besar masyarakat terdampak bencana menggunakan air dari PDAM untuk kepeluan memasaknya, selebihnya menggunakan sumur dan sebagian kecil menggunakan air kemasan. Sedangkan untuk kepeluan MCK masyarakat masih menggunakan sumber air PDAM mencapai 57,9\%, artinya bahwa keperluan penggunaan air untuk aktivitas MCK masih bergantung penyediaanya pada PDAM. Untuk sumber air sumur yang dimanfaatkan oleh masyarakat dalam kegiatan MCK mencapai 41,2\%, sumur tersebut dibuat sendiri oleh masyarakat oleh setiap kepala keluarga (KK). Sumber air lainnya seperti air sungai, embung, tadah hujan dan lain-lain tidak pernah dimanfaatkan oleh masyarakat untuk keperluan sehari-hari, selain sumber air tersebut juga kotor dan berbau.

Sumber air bersih yang selama ini disediakan oleh PDAM dan air sumur yang dibuat oleh sebagian KK di RW 07 dan RW 08 Kelurahan Bareng menurut masyarakat sudah baik, kualitas airnya berdasarkan indikator bersih, jernih, tidak berwarna dan tidak berbau mencapai 81\%. Dari prosentase tersebut pemakaian air berkualitas yang digunakan masyarakat untuk keperluan sehari-hari sudah terpenuhi, meskipun masih ada diantara masyarakat yang belum mendapatkan sumber air yang berkualitas, sebesar 9,65\% yang menyatakan air yang mereka dapatkan bersih tetapi tidak jernih, berwarna meskipun tidak berbau. Selebihnya kualitas airnya bersih, jernih, tidak berwana namun masih berbau sebanyak $6,14 \%$ masih didapatkan oleh sebagian dari masyarakat. Dengan pemaparan diatas, dapat dijelaskan bahwa hampir sebagian besar masayarakat di daerah terdampak bencana di Kelurahan Bareng masih mendapatkan sumber air bersih dan berkualitas.

Dalam hal pemanfaatan sumber mata air, memang hanya ada di RW 08 yang memiliki potensi sumber mata air diluar yang disediakan oleh pemerintah Kota Malang melalui pelayanan PDAM. Kendati keberadaannya belum termanfaatkan, dilembagakan dan dikelola mandiri oleh masyarakat layaknya Himpunan Penduduk Pemakai Air Minum (HIPPAM) di daerah lain seperti di Kota Batu dan Kabupaten Malang. Meskipun demikian, baik di RW 07 dan RW 08 berdasarkan hasil survei menyebutkan bahwa untuk pemanfaatan sumber air bersih yang ada dalam masyarakat baik dari sumber mata air, belik, embung, sumur bor dan yang lainnya sebanyak $56 \%$ menyatakan setuju untuk menjadi pelanggan. Bahkan sejumlah $21 \%$ diantara mereka siap menjadi pengurus apabila pengelolaannya diberikan kepada masyarakat.

Jaringan Sanitasi dan Limbah, wilayah RW 07 dan RW 08 Kelurahan Bareng Kecamatan Klojen termasuk dalam lingkungan perkotaan yang padat penduduknya, Adapun dalam hal jaringan sanitasi dan 
limbah, termasuk belum mendapatkan akses layanan air limbah yang layak. Sebagaimana pemaparan yang disampaikan masyarakat melalui survei, sebesar 92,98\% menyatakan bahwa keberadaan sungai yang ada di lingkungannya selama ini digunakan untuk penampungan air hujan dan limbah cair rumah tangga, termasuk kegiatan MCK. Bahkan mencapai 88,60\% warga disetiap KK memiliki Kamar mandi dan WC dengan saluran dibuang ke sungai/ aliran air sungai. Selebihnya sebesar 4,39\% KK memiliki kamar mandi dan WC dengan septic tank kurang memadai atau seadanya. Meski demikian, masih ada KK yang memiliki kamar mandi dan WC dengan septic tank yang memadai dengan prosentase yang sedikit yaitu sebesar $4,39 \%$.

Berdasarkan penjelasan diatas, hampir dari setengah KK warga RW 07 dan RW 08 Kelurahan Bareng memiliki kamar mandi dan WC, tetapi tidak memiliki septic tank. Artinya, bahwa pengolahan limbah cair rumah tangga dan pembuangan kotoran/ tinja dilakukan dengan cara dibuang langsung ke sungai atau lahan terbuka. Hanya sedikit dari warga yang memiliki septic tank, dengan kondisi septic tank sebagian ada yang memadai dan sebagian lagi dengan kualitas seadanya/ kurang memadai serta tidak diketahui apakah sudah sesuai dengan standar nasional yang telah ditentukan oleh pemerintah tentang jaringan sanitasi dan limbah yang berkualitas dan tidak mencemari kualitas air bawah tanah.

Namun demikian, sebagian warga RW 07 dan RW 08 Kelurahan Bareng menyadari bahwa jaringan sanitasi dan limbah yang memadai sangat diperlukan sebagai upaya menciptakan kualitas lingkungan yang lebih baik dan berdampak pada kesehatan masyarakat dan air bawah tanah yang bersih. Bahkan berdasarkan survei, sebagian warga masyarakat menyatakan setuju sebesar $29,82 \%$ untuk pembangunan septic tank terpadu di beberapa RT/KK, sebagian lagi dengan prosentase yang sama menyatakan ketidak setujuannya.

Meskipun dalam Focus Group Discussion (FGD) warga masyarakat yang tidak setuju menyatakan bahwa pendapatnya tersebut karena alasan ketidaktahuannya dan kekhawatiran jaringan sanitasi yang dibuat dapat mempengaruhi kualitas air bawah tanah yang mereka miliki, selain itu pula ketersediaan lahan yang tidak ada atau terbatas. Selanjutnya dalam kegiatan FGD tersebut juga warga masyarakat sependapat dan menyetujui dibangunnya jaringan saanitasi dan limbah yang memadai dan terstandar (SNI) melalui Instalasi Pengelohan Air Limbah (IPAL) Komunal dengan teknologi yang memadai, terutama tidak mencemari lingkungan dan jaringan sumber air bersih yang dimiliki warga masyarakat.

Lebih dari itu warga masyarakat RW 07 dan RW 08 tidak hanya menyutujui pembangunan IPAL Komunal di lingkunannya, tetapi juga akan membantu dalam pengelolaannya, hal ini sebagaimana digambarkan dalam hasil survei yang menyatakan bahwa sebesar $22,81 \%$ warga setuju untuk membantu pengelolaan IPAL Komunal. Dengan demikian, proses pembangunan IPAL Komunal berdasarkan hal tersebut memang dilakukan melalui konsep pembangunan berbasis masyarakat, dimana masyarakat dilibatkan dalam setiap tahapan pembangunan mulai dari perencanaan, pengambilan keputusan, pembangunan, pengoperasian dan perawatan. Dalam pembangunan dan pengoperasian sarana pegelolaan air limbah kedepannya dibentuk lembaga pengelola ditingkat masyarakat yang beranggotakan masyarakat pengguna layanan.

Untuk lahan yang digunakan bagi pembangunan IPAL Komunal, warga RW 07 dan RW 08 sejumlah 41,2\% menyatakan bahwa jalan kampung dapat digunakan untuk jaringan sanitasi dan limbahnya, sebagian lagi menyatakan agar menggunakan lahan lainnya yaitu sebesar 36,8\%, meskipun tidak memberikan alternatif solusi untuk lahan yang dijadikan tempat pembangunan IPAL Komunal. Artinya bahwa dari hasil survei tersebut, dari alternatif lahan yang ada, lahan fasilitas umum (fasum) sudah tidak punya, tanah perorangan tidak memungkinkan dan lahan dibawah aliran sungai juga tidak bisa digunakan, maka hanya lahan jalan kampung saja yang memungkinkan untuk tempat pembangunan IPAL Komunal, demikian pula hasil FGD menyatakan hal yang sama bahwa lahan tersebutlah yang masih bisa dipakai dengan tetap mengedepankan teknologi jaringan sanitasi dan limbah yang memadai untuk lingkungan sekitarnya.

\section{Pemetaan Potensi Ekonomi Masyarakat Terdampak Bencana Kelurahan Bareng Kota Malang}

Potensi Sumber Daya - Elemen sumber daya yang memberikan kontribusi cukup besar antara lain sumber daya manusia, potensi sumber daya bahan baku, potensi wilayah, potensi iklim usaha, dan potensi pasar. Dari sisi sumber daya manusia, hasil survei lapangan dan juga FGD yang telah dilakukan beberapa elemen pertanyaan tentang hubungan interaksi sosial antar warga tidak mendapatkan masalah yang menjadi hambatan terlaksananya pengembangan potensi ekonomi di kawasan keluraha bareng. Perihal komiten, kerjasama dan juga dukungan lingkungan cukup besar mngarah pada usaha peningkatan perekonomian warga. Jika dilihat dari jumlah potensi sumber daya manusia produktif hampir sebanding dengan jumlah manusia tidak produktif. Namun lebih dari $80 \%$ warga menginginkan usaha mengembangan perekonomian secara berkelanjutan. 
Kemampuan dan keterampilan warga bareng dalam memngelola bisnis dapat dilihat dari beberapa pertanyaan dan diskusi tentang bagaimana pengetahuan atau penglaman yang mereka miliki dalam mengelola sebuah bisnis, memang dari permasalahan yang sangat dominan adalah permodalan sebanyak kurang lebih $85 \%$, aspek lain seperti pemasaran, kapasitas produksi dan pengelolaan keuangan juga berada diposisi rata diatas 55\%, hal ini mangamsumsikan bahwa warga pernah menghadapi permasalahan-permasalahan tersebut, dan dalam usaha pengembang ini hal tersebut menjadi prioritas dibawah permasalahan modal. Maka sumber daya manusia Kelurahan Bareng dapat dikatakan siap dan mampu untuk menjalankan program pengembangan perekonomian tersebut.

Sedangkan terkait potensi sumber daya bahan baku, kondisi ketersediaannya di daerah Bareng tentunya masih cukup sangat terjangkau, memang semuanya akan disesuaikan dengan produk apa yang akan diciptakan. Tetapi dalam kapasitas kecil, bahan baku cenderung akam mudah untuk didapatkan. Hal ini dikarenkan posisi atau letak geografis dari Kelurahan Bareng yang berdekatan dengan sumber bahan baku misalnya seperti pasar bareng, pasar besar, comboran. Hanya saja hal yang perlu diwaspadai dalam rangka menyediakan bahan baku adalah akses untuk mencapai lokasi atau tempat produksi, mengingat tata letak pemukiman keluraha bareng yang sangat padat rumah tempat tinggal permanen.

Potensi wilayah merupakan potensi yang sebenarnya memiliki kelebihan yang cukup berpengaruh, bisa dikatakan lokasi wilayah Kelurahan Bareng berada ditengah Kota Malang, artinya pusat keramaian dan pusat aktifitas masyarakat Kota Malang dapat dengan mudah menjangkau wilayah Kelurahan Bareng. Hal ini sangat mempengaruhi kelancaran aktifitas produksi yang diarapkan, akses perolehan bahan baku sampai akses kedatangan konsumen mudah dicapai. Sehingga mempersingkat proses produksi mulai input sampai ke output serta meminimalkan biaya pengiriman bahan baku maupun barang jadi. Hanya saja karena tata letak pemukiman Kelurahan Bareng terbatasi oleh sempitnya akses jalan masuk untuk sebagian besarnya maka proses perpindahan barang yang memiliki volume besar secara fisik perlu diperhitungkan kembali. Namun hal ini menunjukkan jauga bahwa bisnis dengan kapasitas atau volume besar kurang begitu cocok untuk diterapkan.

Potensi iklim usaha - Berdasarkan hasil survei dan FGD, kehidupan sosial masyarakat bareng yang cukup dinamis dan juga status pekerjaan yang lebih banyak di sektor nonformal tentu menjadi salah satu fariabel yang menentukan bagaimana iklim bisnis yang diterapkan. Hal ini menunjukan hubungan yang signifikan antara pekerjaan nonformal dengan hubungan atau interaksi sosial masyarakan. Pada umumnya area atau kawasan yang mayoritas bekerja pada sektor formal menunjukan hubungan interaksi sosial yang statis. Jadi, tentu iklim persaingan bisnis tentunya dapat diperkirakan akan ada pada hubungan persaingan yang lebih sehat. Karena peluang untuk mendeferensiasikan produk cukup besar, artinya besar juga peluang untuk menciptakan produk yang berbeda karena ada pada segmentasi pasar yang cukup luas.

Potensi Pasar - Kelurahan bareng yang terletak di tengah pusat aktifitas Kota Malang sangat mendukung jarak kedekatan antara produk dengan konsumennya. Tetapi menurut pengalaman warga dari hasil survei pada dasarnya menyadari hal tersebut, namun mereka menganggap bahwa pasar terdekat mereka khususnya radius malang kota tidak mempunyai potensi yang besar. Buktinya produk yang pernah mereka coba untuk diproduksi dan dijual tidak terlalu diminati.

Berdasarkan analisa FGD memberikan gambaran bagaimana produk-produk yang sebelumnya pernah mereka ciptakan dengan berbagai macam manajemen pengelolaanya. Pada dasarnya keberhasilan penetrasi pasar tentu perlu dukungan dari beberapa faktor yang menentukan. Faktor-faktor yang membantu keberhasilan penetrasi pasar antara lain, ketepatan kesesuaian produk yang diciptakan, strategi promosi, dan tentu faktor pelayanan yang prima. Jadi kedepannya terkait dengan potensi kedekatan pasar tersebut hendaknya mulai mengkalisifikasikannya pada segmentasi-segmentasi pasar tertentu.

Potensi usaha - Terdapat tiga bidang utama yang diharapkan, pertama adalah bidang usaha perdagangan $89,5 \%$, kerajinan tangan $57 \%$, dan usaha jasa 57\%. Jadi ketiga bidang usaha ini dapat dikatakan layak untuk dilaksanakan. Dari bidang usaha perdagangan yang diminati juga terdapat tiga bsar jenis yang diharapkan antara lain perdagangan kaki lima sebesar 86,2\%, warung kelontong 80,7\%, dan warung makan kuliner khas sebesar 67,5\%. Sedangkan dari bidang kerajinan tangan ada sebesar 45,6\% untuk daur ulang ban bekas, 44,7\% untuk jenis usaha koveksi dan 42,1\% untuk anyaman dari bahan limbah RT. Lalu terdapat 43,9\% usaha service elektronik, 40,4\% salon dan potong rambut dan $38,6 \%$ pertukangan pada bidang usaha jasa.

Hasil survei dan FGD menyatakan beberapa pilihan bidan usaha dan juga bidang usaha yang diminati kurang dapat begitu fokus untuk diterapkan. Tentu diperlukan analisa yang mendalam untuk menentukan bidang dan jenis mana yang paling sesuai. Sangat tidak memungkinkan jika peminatan ini dijadikan tolak ukur secara merata untuk mengakomodir semuanya. Diharapkan dalam analisa ini bisa menentuka prioritas bidna dan jenis usaha mana yang akan didahulukan. Variabel indikator yang sangat 
memungkinkan pengukuran kelayakan tersebut adalah asumsi atau prediksi produk nantinya kan berintegrasi dengan diferensiasi produk yang lain.

Volume usaha - Besar kecilnya bidang dan jenis usaha yang akan dijalankan sangat dipengaruhi oleh keseuaian antara potensi sumber daya yang dimiliki dengan luasnya pasar yang akan dibidik. Jika dilihat dari potensi sumber daya khususnya kewilayahan atau tata letak area tentu akan menjadi permasalahan yang mendasar jika akan menerapkan bisnis dengan kapasitas yang besar, keterbatasan area atau lokasi di rumah masing-masih warga ataupun tempat fasilitas umum tentunya perlu diperhitungkan kembali. Kecuali jenis produk mampu diproduksi di masing-masing rumah warga denngan kapasitas yang kecil lalu dikumpulkan di area yang lebih luas. Jadi dari analisa tersebut maka lebih memunginkan untuk menciptakan produk dengan kapasitas yang kecil atau bervolume kecil dengan keanekaragaman yang tinggi dan juga tingkat diferensiasi produk yang juga tinggi.

Produktifitas usaha adalah cerminan dari besar dan kecilnya sejumlah aktifitas untuk penciptaan sebuah produk yang efektifitasnya diukur melalui keseimbangan Anantara kualitas dan kuantitas. Dalam hal ini keterbatasan-keterbatan sumberdaya manusia, sumberdaya bahan baku, teknologi dan lain-lain yang ada pada keluraha bareng tentunya dijadikan sebagai acuan dalam menentukan strategi bisnis pada produk tertentu. Sehingga ketika ada kesesuaian antara produk dan harapan konsumennya maka disitulah indikator keberhasilan dari produktifitas yang maksimal.

Potensi pengambangan usaha dikhususkan untuk mereka yang telah atau pernah atau sedang memiliki usaha sampingan. Pernyataan ini dimaksudkan agar kita dapat menggali kepada mereka sebagai pelaku bisnis tentang permasalahan yang sering menghambat mereka. Dari hasil wawancara tidak ditemukan bidan atau jenis usaha yang mengalami peningkata atau pertumbuhan yang signifikan mulai dari berdirinya usaha tersebut sampai sekarang. Hasil survei juga menyatakan 79,55\% dari mereka menginginkan untuk terus mengmbangkan usahanya. Dalam perihal pengembangan usaha tentunya mereke telah memprioritaskan kepada hal-hal tertentu yang menjadi kendala utama dalam pengembangan bisnis mereka. Terdapat $89,9 \%$ dari mereka menyetakan memprioritaskan untuk penambahan modal, $89,9 \%$ juga menyatakan akan meningkatkan volume usaha mereka, $86,49 \%$ menyatakan ingin melakukan perluasan pasar dan 78,38\% akan membangun atau mengembangkan jaringan usaha melalui kemitraan. Dari keterangan tersebut ada empat rencana yang mereka prioritaskan untuk usaha pengembangan bisnis.

\section{Aspek bidang usaha}

Untuk usaha yang sudah berjalan aspek bidang usaha tentunya menitikberatkan pada integrasi usaha yang memungkinkan. Integrasi ini bisa bersifat vertikal maupun horizontal. Pengembangan bisnis ini juga bisa mengarah pada pengembangan kapsitas jika memungkinkan. Khususnya pada warga bareng yang telah memiliki usaha terdapat sebanyak $97,3 \%$ yang memiliki permaslahan permodalan yang ditujukan untuk pengembangan kapasitas. Pengembangan kapasitas ini perlu dianalisa kembali prioritasnya karena belum tentu pengembangan kapasitas tersebut sebanding dengan jumlah permintaan konsumennya. Terkadang obsesi untuk mengembangkan kapasitas ini hanya dikarenakan harapan mendapat keuntungan yang lebih besar. Perlu perhitungan yang lebih matang, dalam artian apakah jaminan perluasan pasar pasti ada maupun jaringan atau mitra bisnis yang mendukung seperti misalnya suplier bahan baku.

Dalam hal pengambangan jenis usaha terdapat dua strategi yang dapat dilakukan, yang pertama adalah inovasi dalam artian memodifikasi produk utama untuk bisa mendapatkan segmentasi baru, pilihan strategi yang kedua adalah dengan cara menciptakan barang substitusinya atau barang pendukungnya yang masih terkait. Berdasarkan data yang didapatkan, motivasi untuk inovasi produk atau penganekaragaman produk lebih besar sebanyak $64,86 \%$ dibanding dengan menambah atau menciptakan produk baru sebesar 45,95\%. Dari angka tersebut dapat diartikan bahwa warga bareng yang sudah memiliki usaha tersebut masih ragu dalam inovasi produk atau mengembangkan ke produk baru. Jadi yang masih lebih banyak menjadi tujuannya adalah pengembangan kapasitas saja.

\section{Aspek volume}

Pengembangan kapasitas produksi menjadi tujuan utama yang diminati oleh para pelaku bisnis di Kelurahan Bareng dan permasalah tertinggi yang didapatkan adalah aspek permodalan. Jadi ketika mereka mendapatkan modal tersebut, prioritas pertama yang akan dilakukan adalah pengembangan kapasitas. Pengembangan kapasitas sangat memungkinkan untuk dilakukan kitika pelaku bisnis sudah mengetahui dengan pasti faktor pendukung seperti perluasan pasar dan inovasi produk jangka panjang sudah direncanakan dengan matang. Perlu adanya tahapan yang pasti dan berdasarkan indikator yag jelas pada setiap tahapan pengembangan kapasitsnya. Berdasarkan hasil FGD juga didapatkan, pelaku bisnis tidak memperhitungkan secara detail sebesar apa pengembangan yang diinginkan. 


\section{Aspek produktifitas}

Penilaian aspek produktifitas yang dapat dievaluasi adalah rutinitas jumlah produksi yang dihasilkan, berdasarkan wawancara dan FGD memberikan keterangan bahwa rata-rata dari usaha yang mereka kelola kebanyakan belum pada posisi memproduksi dengan jumlah yang rata-rata sama. Artinya mereka lebih banyak memproduksi berdasarkan permintaan yang ada. Jumlah rata-rata permintaan konsumen juga dalam posisi yang tidak menentu. Sangat sedikit dari pelaku bisnis yang ada di Kelurahan Bareng mengelola bisnis dengan mengambil risiko menyediakan stok barang diatas jumlah permintaan yang ada. Maka dapat ditarik kesimpulan bahwa aspek produktifitas sebenarnya masih ada diposisi yang sangat tidak menentu berdasarkan jumlah permintaan saja.

\section{Gambaran permasalahan yang dihadapi}

Hasil survei menyatakan bahwa 71,05\% warga Kelurahan Bareng menginginkan penciptaan usaha baru dan $28.95 \%$ mereka tidak menginginkan untuk menciptakan usaha baru dikarenakan merasa kurang sehat dan sudah berumur lanjut, mereka juga menyataka tidak memiliki waktu yang cukup untuk mengelola bisnis.

Permasalahan utama yang dihadapi adalah aspek permodalan dan variabel-variabel yang menentukan permasalahan ini antara lain secara berurutan menyatakan bahwa kurangnya modal usaha, prosedur pengrusan kredit, pengembalian kredit yang memberatkan, kurangnya akses informasi, dan kurangnya minat penanaman modal, menjadi masalah yang sampai saat ini belum mendapatkan solusi. Para calon pelaku usaha pada keluraha bareng menganggap kunci keberhasilan mereka untuk memulai dan mengelola bisnis adalah aspek permodalan.

Sumber daya manusia masyarakat Kelurahan Bareng bisa dikatakan cukup tersedia, dalam artian jumlah orang usia produktif yang masih memiliki waktu untuk mengelola usaha secara mandiri ataupun kelompok masih tersedia. Berdasarkan hasil FGD menyatakan walaupun mereka yang sudah memiliki pekerjaan di sektor formal ataupun nonformal masih dapat menyediakan waktu untuk mengelola usaha sampingan. Terdapat sebagian besar usia lanjut yang merasa sudah tidak mampu untuk mengelola usaha, tetapi dirasa sebagian kecil saja.

Dari aspek sumber daya manusia permasalahan yang paling banyak dihadapi adalah mengenai penguasaan teknologi pengolahan produk sebanyak $69,30 \%$ dan juga mengenai kurangnya daya kreatifitas dan inovasi sebanyak $68,42 \%$. Sedangkan permasalahan yang lain seperti pengetahuan tentang pemasaran produk, keberanian mengambil risiko, keterbatansan keterampilan, keterbatasan waktu kurangnya motivasi dan penguasaan manajemen usaha juga menjadi permasalahan antara sebesar 40\%-50\%, hal ini menunjukkan bahwa sebenarnya sebagian besar mereka yang berpengalaman maupun yang tidak berpegalaman memiliki problematika yang sama. Pada dasarnya ketahanan mereka dalam mengelola dan mengembangkan usaha bisa dikatakan kurang. Kurangnya faktor pendukung seperti pelatihan manajemen usaha dan juga informasi dalam mengakses modal tentu menjadi pengaruh yang cukup kuat dalam permasalahan ini. Tetapi perihal ketersediaan dan minat yang ada pada warga Kelurahan Bareng menjadi modal utama dalam keberhasilan program-program yang akan dilakukan .

Permasalahan lain yang muncul pada warga Kelurahan Bareng dalam mengelola usaha adalah teknologi. Pada dasarnya ketersediaan mengacu pada tingkat pengetahuan atau pengalaman yang mereka miliki. Ada dua kategori yang dapat diklasifikasikan pada permasalahan ini yang pertama adalah pengembangan teknologi yang berasal dari mereka sendiri, artina inovasi tekologi adalah hasil dari pengembangan modifikasi dari perhitungan dan pertimbangan mereka sendiri, hanya saja permasalahannya dikaitkan dengan permodalan. Yang kedua adalah perihal kurangnya pengetahuan dan informasi tentang teknologi dari pihak lain, tentunya permasalahan ini karena tidak adanya mitra atau pihak yang mendukung untuk pemikiran pengembangan usaha berdasarkan pengembangan teknologi. Hal ini sesuai dengan hasil survei yang telah dilakukan menyatakan bahwa $61,40 \%$ mermasalahan utama terletak pada kurangnya akses dan informasi teknologi, sedangkan mengenai pemeliharaan teknologi, prosedur untuk mendapat distribusi bantuan tenologi, kualitas alat, dan ketersediaan teknologi tepat guna juga menjadi problem yang cukup merata sebesar 40-50\% diprioritaskan.

Dalam menentukan segmentasi pasar tentu harus leih difokuskan pada definisi strategi bisnisnya, pada dasarnya masalah ketersediaan pasar tentu disesuaikan dengan produknya. Selama ini kebanyakan dari mereka yang telah memiliki pengalaman memproduksi produk pengikut saja, artinya produk yang mereka ciptakan menyesuaikan saja dengan pasar yang sudah ada. Maka terjadi persaingan yang sulit untuk dimenangkan, karen keterbatasan kapasitas yang dimilikinya. Dari hasil survei mengenai permasalahan utama di bidang pemasaran adalah menentukan pangsa pasar sebesar 54,39\% dan juga penguasaan manajemen pemasaran sebesar 53,51\% menyimpulkan bahwa sebenarnya produk yang dihasilkan, strategi yang dijalankan dan segmentasi yang dituju belum seimbang dengan harapan keuntungan. jadi pada 
dasanya karena permasalahan tersebut menjadikan taget pasar manjadi kurang tepat, dan penciptaan produk menjadi kurang maksimal, mereka hanya akan terus menurunkan harga jual dikarenakan mengikuti aktifitas pasar yang lebih besar.

Berdasarkan hasil survei, FGD dan pengamatan langsung yang dikaitkan juga dengan posisi kewilayahan Kelurahan Bareng maka sebenarnya masalah ketersediaan bahan baku tidak menjadi masalah yang berpengaruh besar. Dari beragam jenis usaha yang ada masih memungkinkan untuk dapat mengakses atau memenuhi bahan bahan baku yang diharapkan sesuai dengan batasan kapasitasnya. Permasalahan utama yang sebenarnya adalah harga bahan baku sebesar $70,18 \%$ artinya bisa jadi bahan baku yang memang berharga mahal materialnya ataupun karna fluktuasi harga bahan baku. Pada kondisi pasar yang belum fokus, aktifitas produksi yang juga belum menentu, makan akan menjadi problem yang besar untuk membuat keputusan pembelian bahan baku. Pembelian bahan baku dengan jumlah besar ataupun kecil tentu menjadi masalah yang kompleks, ditambah lagi dengan biaya-biaya lain yang terkandung didalamnya.

\section{Kesimpulan, Saran dan Rekomendasi}

Berdasarkan hasil survei maka bidang usaha yang telah ditekuni oleh masyarakat sebagai modalitas dalam pengembangan ekonomi, jika selama ini Sanan dikenal dengan produk Kripik Tempe, Dinoyo dikenal dengan produk keramiknya, maka Kelurahan Bareng selama ini telah dikenal dengan penghasil Gethuk yang cukup terkenal di Kota Malang. Namun imbas dari perkembangan modernisasi membuat gethuk kurang diminati oleh konsumen menyebabkan usaha gethuk di Kelurahan Bareng tidak dapat bertahan lama. Usaha yang pernah digeluti oleh masyarakat Kelurahan Bareng ini merupakan modalitas ekonomi yang dapat dikembangkan lagi sebagai sumber penghasilan. Untuk itu, hal-hal yang perlu dilakukan yatu diversifikasi produk dari bahan gethuk.

Berdasarkan data yang didaptkan beberapa contoh bidang dan jenis usaha yang pernah bahkan sampai sekarang masih berlangsung. Pada dasarnya beberapa bidang usaha ini belum mengakomodir warga secara lebih merata, hanya dikelola oleh sebagian kelompok kecil saja. Permasalahan lain yang didapatkan adalah kurangnya strategi bisnis yang disesuaikan dengan produk dan konsumennya. Maka dari fenomena tersebut diperlukan penataan kembali tatakelola atau struktur organisasi yang jelas dan efektif lalu menyesuaikan strategi bisnis dengan sekmentasi konsumennya secara berkelanjutan.

Untuk membuka bidang usaha baru tentu diperlukan perencanaan yang matang, berdasarkan hasil surve bidang usaha perdagangan, kerajinan tangan dan juga bidang jasa menduduki peringkat tertinggi, namun dari hasil FGD didapatkan informasi tambahan tentang bagaimana sebenarnya yang lebih dapat untuk segera diprioritaskan untuk dijalankan. Untuk bidang usaha jasa yang juga menduduki peringkat tinggi ternyata hanya bersifat keinginan yang belum tentu mampu mengukur kemmpuan teknis pelaksanaannya, selanjutnya bidang usaha jasa yang diharapkan belum tentu dapat berdampak secara luas untuk warga, kecederungan hanya pada individu tertentu sangat memungkinkan, bidang usaha jasa dalam kapasitas kecil membutuhkan waktu yang lebih lama untuk mendapatkan konsumen yang lebih luas, artinya pengguna jasa tersebut cenderung hanya berasal dari lingkungan sekitar saja.

Berdasarkan analisa tersebut maka rekomendasi yang diberikan lebih memfokuskan pada usaha perdagangan dan kerajinan tangan, pada bidang perdagangan jenis usaha yang paling memungkinkan untuk dijalankan adalah usaha jenis kuliner yang berupa makanan atau minuman khas ataupun makanan khas. Jenis usaha ini didukung oleh banyaknya keterampilan memasak yang dimiliki oleh warga, Kelurahan Bareng juga pernah menyandang sebagai daerah penghasil getuk malang. Dengan memfokuskan pada beragam jenis kuliner khas diharapkan dapat lebih berdampak luas untuk warga.

\section{Model pengelolaan usaha baru (program);}

Pengelolaan usaha makanan dan minuman khas akan dikelola oleh kelompok yang bertugas sebagi fungsi pemasaran dan keuangan saja. Sedangkan operasional penciptaan produk dialankan oleh masing-masing jenis produk sesuai dengan kelompoknya. Kelompok inti bekerja fokus untuk memasarkan dengan cara online dan juga mengelola outlet (jika disediakan) sedangkan bagian keuangan secara administratif mengelola pemasukan dan pengeluaran uang. Kelompok pendukung sebagai yang menciptakan dan memproduksi produk sesuai dengan jumlah permintaan dari kelompok inti. Kelompok pendukung minimal beranggotakan 3 orang.

\section{Model implementasi program (madiri, pendampingan/fasilitasi, pilot project)}

Metode pendampingan lebih diharapkan warga Kelurahan Bareng dengan alasan dibutuhkan pendampingan intens secara berkelanjutan. Tahapan pertumbuhan dan pengembangan perlu dibuat atas dasar kesepakatan bersama. Tim pendamping membuat indikator capaian pada masing-masing tahapan pertumbuhan dan selalu mengevaluasi sampai pada titik dimana usaha ini mampu untuk bekerja secara mandiri.

\section{Bidang Sanitasi dan Lingkungan}


Berdasarkan hasil Focus Group Discussion (FGD), disimpulkan bahwa sebagian besar masyarakat sebenarnya menerima penataan lingkungan hidup sehat, melalui pengembangan sanitasi dengan model terpadu yaitu berupa Instalasi Pengolahan Air Limbah Komunal (IPAL-Komunal). Namun sebagian besar warga menyarankan bahwa:

1. Revitalisasi sungai disekitar RW 7 dan RW 8, dengan mengupayakan terwujudnya aliran sungai yang bersih dan sehat. Karena selama ini aliran sungai oleh warga difungsikan sebagai saluran pembuangan limbah rumah tangga dan limbah MCK, salah satunya melalui pembangunan IPAL Komunal.

2. Pembangunan IPAL Komunal hendaknya dimulai dari kawasan atas aliran sungai (bagian wilayah RT 15 RW 8), sehingga jika bagian bawah aliran sungai sudah dibangun IPAL tidak dikotori lagi oleh warga bagian atas.

3. Mengingat rata-rata luas areal tanah dan bangunan yang dimiliki warga relatif sempit dan saling berdekatan, maka diharapkan agar pembangunan IPAL Komunal menerapkan teknologi yang memungkinkan septic tank yang dibangun tidak bocor dan mencemari sumber air bersih yang dimiliki warga.

\section{Referensi}

Awange, J. L. (2012). Disaster management. In Environmental Science and Engineering (Subseries: Environmental Science). https://doi.org/10.1007/978-3-540-88256-5_14

Lindell, M. K. (2013). Disaster studies. Current Sociology. https://doi.org/10.1177/0011392113484456

Rathore, F. A., Gosney, J. E., Reinhardt, J. D., Haig, A. J., Li, J., \& Delisa, J. A. (2012). Medical rehabilitation after natural disasters: Why, when, and how? Archives of Physical Medicine and Rehabilitation. https://doi.org/10.1016/j.apmr.2012.05.018

Reinhardt, J. D., Li, J., Gosney, J., Rathore, F. A., Haig, A. J., Marx, M., \& DeLisa, J. A. (2011). Disability and health-related rehabilitation in international disaster relief. Global Health Action. https://doi.org/10.3402/gha.v4i0.7191

Tingsanchali, T. (2012). Urban flood disaster management. In Procedia Engineering. https://doi.org/10.1016/j.proeng.2012.01.1233

Victoria, L. P., Director, Preparedness, C. for D., \& Center for Disaster Preparedness. (2002). Community Based Approaches to Disaster Mitigation. Regional Workshop on Best Practices in Disaster Mitigation. 
